\title{
Comparison of Nanosized Gold-Based and Copper-Based Catalysts for the Low-Temperature Water-Gas Shift Reaction
}

\author{
Diogo Mendes, ${ }^{\dagger}$ Hermenegildo Garcia, ${ }^{\ddagger}$ V. B. Silva, ${ }^{\dagger}$ Adélio Mendes, ${ }^{\dagger}$ and Luis M. Madeira*, ${ }^{\dagger}$ \\ LEPAE, Chemical Engineering Department, Faculty of Engineering, University of Porto, Rua Dr. Roberto \\ Frias, 4200-465 Porto, Portugal, and Instituto de Tecnología Química, UPV-CSIC, Universidad Politécnica de \\ Valência, Av. de los Naranjos s/n, 46022 Valencia, Spain
}

\begin{abstract}
In this paper the catalytic performances for the low-temperature water-gas shift reaction of $\mathrm{Au} / \mathrm{TiO}_{2}$ type $\mathrm{A}$ (from World Gold Council), $\mathrm{Au} / \mathrm{CeO}_{2}$ (developed at UPV-CSIC), $\mathrm{CuO} / \mathrm{Al}_{2} \mathrm{O}_{3}$ (from $\mathrm{BASF}$ ), and $\mathrm{CuO} / \mathrm{ZnO} /$ $\mathrm{Al}_{2} \mathrm{O}_{3}$ (from REB Research \& Consulting) have been compared. The catalysts were characterized by different techniques such as Raman spectroscopy, BET surface area measurements, temperature-programmed reduction, and high-resolution transmission electron microscopy, which gave additional information on the redox properties and textural and morphological structure of the investigated samples. The performances of these catalysts were evaluated in a wide range of operating conditions in a micro packed-bed reactor. It was observed that the presence of reaction products in the feed $\left(\mathrm{CO}_{2}\right.$ and $\left.\mathrm{H}_{2}\right)$, as well as $\mathrm{CO}$ and $\mathrm{H}_{2} \mathrm{O}$ feed concentrations, have significant effects on the catalytic performances. With a typical reformate feed the $\mathrm{Au} / \mathrm{CeO}_{2}$ catalyst reveals the highest $\mathrm{CO}$ conversion at the lowest temperature investigated $\left(150^{\circ} \mathrm{C}\right)$. However, while in the long tests performed the $\mathrm{CuO} / \mathrm{ZnO} / \mathrm{Al}_{2} \mathrm{O}_{3}$ catalyst showed a good stability for the entire range of temperatures tested $\left(150-300{ }^{\circ} \mathrm{C}\right)$, the $\mathrm{Au} / \mathrm{CeO}_{2}$ sample clearly showed two distinct behaviors: a progressive deactivation at lower temperatures and a good stability at higher ones. The selection of the best catalytic system is therefore clearly dependent upon the range of temperatures used.
\end{abstract}

\section{Introduction}

Anthropogenic carbon dioxide (greenhouse gas) is the most responsible pollutant for increased global warming. It is released into the atmosphere mainly through burning of fossil fuels (e.g., coal, petrol, and diesel), and these emissions are expected to increase following the growth in world population and economy in the coming years. ${ }^{1}$ One of the most important developments, as a clean-alternative energy source for the future, is protonexchange membrane fuel cells (PEMFCs) that operate using hydrogen at low temperatures. In situ fuel processing is a very promising method of supplying hydrogen to PEMFCs due to the difficulties associated with long-distance transportation and hydrogen storage. ${ }^{2}$ In a typical operation, however, gas emerges from the reformer with a $\mathrm{CO}$ level of $1-10$ vol \%, which adsorbs irreversibly on the Pt catalyst of the PEMFC anode, decreasing the fuel cell performance. Therefore, fuel processors must be designed to convert the $\mathrm{CO}$ content in the fuel stream to levels that are tolerated by Pt (less than $100 \mathrm{ppmv}$ ). ${ }^{3}$ In this sense, the water-gas shift (WGS) reaction $\left(\mathrm{CO}+\mathrm{H}_{2} \mathrm{O} \leftrightarrow \mathrm{CO}_{2}\right.$ $+\mathrm{H}_{2}$ ) has been considered and extensively studied. Besides, it simultaneously favors $\mathrm{H}_{2}$ fuel stream enrichment that may be followed by a final purification step, which may involve preferential oxidation or methanation of residual $\mathrm{CO}^{4,5}$ Because the WGS is an exothermic reaction $\left(\Delta H_{298 \mathrm{~K}}=-41.1 \mathrm{~kJ} \mathrm{~mol}^{-1}\right)$, high conversions can only be achieved at low temperatures. On the other hand, under such conditions the reaction is controlled by the kinetics, so highly active and stable low-temperature WGS catalysts are needed.

From the point of view of "on-board" fuel processor applications, these catalysts must obey other requirements, such as nonpyrophoricity and stability toward condensation and poisons

* To whom correspondence should be addressed. Tel: +351 22508

1519. Fax: +351 22508 1449. E-mail: mmadeira@fe.up.pt.

University of Porto.

サniversidad Politécnica de Valência. such as chlorine and sulfur, and additionally should require no exceptional pretreatments. ${ }^{4,5}$ Until recently, the shift reactors in fuel cell systems at the kilowatt scale have utilized industrial iron- and copper-based catalysts. $\mathrm{Fe}-\mathrm{Cr}$ formulations have the advantages of being cheap, stable, and able to withstand gasphase impurities such as $\mathrm{S}$ and $\mathrm{Cl}$ compounds. However, they need temperatures above $350{ }^{\circ} \mathrm{C}$ to be active. ${ }^{6}$ The $\mathrm{Cu}$-based formulations have good activity even below $200{ }^{\circ} \mathrm{C}$, but are susceptible to poison and operate in a limited temperature range due to the $\mathrm{Cu}$ sintering that occurs above $300{ }^{\circ} \mathrm{C} .{ }^{7}$ Other disadvantages of $\mathrm{Cu}$ materials are the need of activation, before operation, by a slow and controlled reduction process. Besides, upon shutdown the catalyst must be purged with an inert gas to prevent condensation and reoxidation; otherwise its performance becomes significantly impaired. Repeated start-up/shutdown cycles, as associated with in-vehicle use, may well result in condensation of water and subsequent deactivation of the catalyst. Extensive research has therefore been conducted looking for better solutions to these well-known commercial WGS catalysts. In fact, the $\mathrm{CuO} / \mathrm{ZnO} / \mathrm{Al}_{2} \mathrm{O}_{3}$ formulation seems to be the reference standard for the development of other WGS catalysts.

Reducible oxide-supported nanosized gold and platinum catalysts seem to be promising candidates for on-board fuel processing, mainly due to their high activity at low temperatures and potential stability in an oxidizing atmosphere. ${ }^{8-10}$ Selection between both catalysts is however delicate because most available data are presented for very specific experimental conditions, not only in what concerns the preparation and pretreatments of the catalysts, but also regarding the operating conditions used in activity tests. Burch ${ }^{11}$ pointed out that a wellprepared, carefully activated gold catalyst can be at least as active as an equivalent platinum catalyst, and if the best available samples are considered, then gold is apparently significantly more active than platinum. Even though gold catalysts have the advantage to possess greater thermal stability than $\mathrm{CuO} / \mathrm{ZnO}$ 
formulations, their activity is very sensitive to the preparative procedure, the gold particle size, and the intimate metal-support contact. $^{11-13}$

High catalytic activity for the WGS reaction using gold-based catalysts operating at low temperature was reported for the first time using nanosized $\mathrm{Au} / \alpha-\mathrm{Fe}_{2} \mathrm{O}_{3}{ }^{14}$ In 1997, Sakurai et al. ${ }^{12}$ used $\mathrm{Au} / \mathrm{TiO}_{2}$ for both forward and reverse WGS reactions presenting high activities. Since that time, many studies have revealed that highly dispersed gold on different metal oxide supports, e.g., $\mathrm{ZrO}_{2},{ }^{15,16} \mathrm{CeO}_{2},{ }^{13,17-19}$ and $\mathrm{Al}_{2} \mathrm{O}_{3},{ }^{14}$ is catalytically active for the WGS reaction at low temperatures. However, the combination of Au with nanosized ceria has apparently been shown to be the most active low-temperature WGS gold catalyst. $^{11,20}$

Due to the lack of a systematic study in which the most promising catalytic systems are tested under similar conditions, in this work the catalytic performances of various commercially available catalysts, namely, $\mathrm{Au} / \mathrm{TiO}_{2}$ type $\mathrm{A}$ (World Gold Council), $\mathrm{CuO} / \mathrm{Al}_{2} \mathrm{O}_{3}$ (BASF), $\mathrm{CuO} / \mathrm{ZnO} / \mathrm{Al}_{2} \mathrm{O}_{3}$ (REB Research $\&$ Consulting), and a laboratory-made one, $\mathrm{Au} / \mathrm{CeO}_{2}$, for conducting the WGS reaction at temperatures ranging from 150 to $300{ }^{\circ} \mathrm{C}$ are compared. The experimental tests were carried out in a micro fixed-bed reactor where criteria parameters such as the $\mathrm{CO}$ conversion level and stability were used to perform catalyst evaluation and selection. The runs were done in a wide range of operating conditions (steam/gas ratio and temperature) under a typical reforming feed composition. Several characterization techniques have also been employed to provide insight into the properties of the investigated samples.

\section{Experimental Section}

2.1. Catalyst Preparation. The gold-ceria sample was prepared by the deposition-precipitation method. First, nanoparticulated ceria was prepared by adding, under stirring, at ambient temperature, an ammonia aqueous solution $(1.12 \mathrm{~L}$, $0.8 \mathrm{M})$ over $375 \mathrm{~mL}$ of $\mathrm{Ce}\left(\mathrm{NO}_{3}\right)_{4}(0.8 \mathrm{M})$. The colloidal dispersion of $\mathrm{CeO}_{2}$ nanoparticles was heated in a poly(ethylene terephthalate) (PET) vessel at $100{ }^{\circ} \mathrm{C}$ for $24 \mathrm{~h}$. The resulting yellow precipitate was filtered and dried under vacuum overnight. The cerium oxide synthesized, which was prepared following a procedure previously described, ${ }^{21}$ has a very high surface area $\left(180 \mathrm{~m}^{2} \cdot \mathrm{g}^{-1}\right)$, owing to the small size of the nanoparticles $(\sim 5 \mathrm{~nm})$. Then $\mathrm{Au}$ was deposited on the nanoparticulated ceria using the following procedure: a solution of $\mathrm{HAuCl}_{4} \cdot 3 \mathrm{H}_{2} \mathrm{O}(270 \mathrm{mg})$ in $160 \mathrm{~mL}$ of deionized water was brought to $\mathrm{pH} 10$ by addition of a $0.2 \mathrm{M} \mathrm{NaOH}$ solution. Once the $\mathrm{pH}$ value was stable, the solution was added to a gel containing colloidal $\mathrm{CeO}_{2}(4.01 \mathrm{~g})$ in $\mathrm{H}_{2} \mathrm{O}(50 \mathrm{~mL})$. After adjustment of the $\mathrm{pH}$ of the slurry to a value of 10 by adding a $0.2 \mathrm{M}$ solution of $\mathrm{NaOH}$, the slurry was maintained at room temperature under vigorous stirring for $18 \mathrm{~h}$. The $\mathrm{Au} / \mathrm{npCeO}_{2}$ solid was then filtered and exhaustively washed with several liters of distilled water until no traces of chlorides were detected by the $\mathrm{AgNO}_{3}$ test. The catalyst was dried under vacuum at room temperature for $1 \mathrm{~h}$. Then $3.5 \mathrm{~g}$ of the supported catalyst was added over $30 \mathrm{~g}$ of 1-phenylethanol at $160{ }^{\circ} \mathrm{C}$, and the mixture was allowed to react for $20 \mathrm{~min}$ (this ensures complete reduction of gold nanoparticles). The catalyst was filtered, washed with acetone and water, and dried under vacuum at room temperature. The total $\mathrm{Au}$ content of the final $\mathrm{Au} / \mathrm{npCeO}_{2}$ catalyst was 1.5 wt \%, as determined by chemical analysis. This catalyst $\left(\mathrm{Au} / \mathrm{npCeO}_{2}\right)$ is commercially available from ITQ (Web page www.upv.es/itq).
The $\mathrm{Au} / \mathrm{TiO}_{2}$ catalyst was bought from the World Gold Council (U.K.) and is referred to as a reference Au catalyst (type A). The $\mathrm{CuO} / \mathrm{Al}_{2} \mathrm{O}_{3}$ sample (CU-1271, Selectra Shift) was supplied by BASF (Germany), and the $\mathrm{CuO} / \mathrm{ZnO} / \mathrm{Al}_{2} \mathrm{O}_{3}$ commercial catalyst $(\sim 50 \mathrm{wt} \% \mathrm{CuO}$ and 40 wt $\% \mathrm{ZnO})$ was acquired from REB Research and Consulting, Ferndale, MI. Both $\mathrm{Cu}$-based catalysts were crushed and sieved to give a particle size of $<180 \mu \mathrm{m}$ (similar to that of the powdered gold solids).

2.2. Catalyst Characterization. The BET surface area of the samples was analyzed by nitrogen adsorption at $77 \mathrm{~K}$ with a Micromeritics 2000 ASAP automated gas sorption analyzer. The samples were exhaustively outgassed at $450{ }^{\circ} \mathrm{C}$ under vacuum before area measurements.

For crystal analysis and indexation, $\mathrm{Au} / \mathrm{npCeO}_{2}$ samples were examined by bright- and dark-field electron microscopy with a Jeol 2200 HRTEM instrument operated at an accelerating voltage of $200 \mathrm{kV}$. Chemical analyses of gold in the catalysts were carried out after the solids were dissolved by attack with a 2:1 mixture of $\mathrm{HNO}_{3} / \mathrm{HF}$ on a Varian-10 Plus atomic absorption spectrometer or directly on the solids using a Philips Minipal $25 \mathrm{fm}$ analytic X-ray apparatus and a calibration plot.

Raman spectra were recorded at room temperature and ambient atmosphere using a Renishaw inVia microscope with a diode laser $(785 \mathrm{~nm})$ and averaging 10 scans of different areas of the black solid.

Finally, temperature-programmed reduction (TPR) measurements were performed in a Micromeritics Autochem 2910 equipped with a TCD detector. The mixture of $10 \% \mathrm{H}_{2}$ in $\mathrm{He}$ as the reducing gas was used in all experiments, and a temperature ramp of $5^{\circ} \mathrm{C} \cdot \mathrm{min}^{-1}$ was employed.

2.3. Experimental Reaction Apparatus, Procedures, and Analysis. The catalytic activity determined for the WGS reaction is expressed as the degree of CO conversion. The experiments were carried out using a micro packed-bed reactor operating isothermally and at atmospheric pressure, as can be seen in Figure 1. The $6 \mathrm{~mm}$ i.d. stainless steel reactor was encased in an electric oven (Memmert, type UNE200), controlled by a programmable temperature controller. The reactor was typically loaded with $250 \mathrm{mg}$ of the catalyst, supported by two fritted Teflon disks to avoid the catalyst powder dispersion over the pipes. In the stability tests, the reactor was loaded with $150 \mathrm{mg}$ of catalyst. A thermocouple was introduced from the top of the reactor, and it was placed at the center of the catalyst bed, which was shown to operate under isothermal conditions (within \pm 2 $\left.{ }^{\circ} \mathrm{C}\right)$.

All the WGS catalysts were activated in situ with a mixed gas flow of $\mathrm{H}_{2} / \mathrm{N}_{2}$ measured by means of mass flow controllers. The reduction protocols applied were based on literature information to ensure complete metal oxide reduction, without sintering. ${ }^{22,23}$ For $\mathrm{Cu}$-based catalysts the prereduction protocol considers heating the catalyst, in nitrogen, from room temperature to $80{ }^{\circ} \mathrm{C}$; then the reduction mixture $\left(5 \mathrm{vol} \% \mathrm{H}_{2} / \mathrm{N}_{2}\right.$, total flow rate of $30 \mathrm{~mL}_{\mathrm{N}} \mathrm{min}^{-1}$ ) is admitted, and the samples are heated at $5^{\circ} \mathrm{C} \cdot \mathrm{min}^{-1}$ from 80 to $230{ }^{\circ} \mathrm{C}$ and maintained at this temperature for $4 \mathrm{~h}$. Nevertheless, the terminology used when referring to these samples is the commercial one, which makes reference to the copper oxide state. For Au-based catalysts the prereduction protocol considers heating to $200{ }^{\circ} \mathrm{C}$ in a $\mathrm{N}_{2}$ stream and keeping the solids at this temperature for $30 \mathrm{~min}$. Subsequently, reduction is performed for $45 \mathrm{~min}$ in a $10 \mathrm{vol} \% \mathrm{H}_{2} /$ $\mathrm{N}_{2}$ stream (at a total flow rate of $30 \mathrm{~mL}_{\mathrm{N}} \mathrm{min}^{-1}$ ), followed by 30 min in a $\mathrm{N}_{2}$ flow, both at $200{ }^{\circ} \mathrm{C}$. In all cases, after reduction, the catalysts were cooled or heated to the reaction temperature 


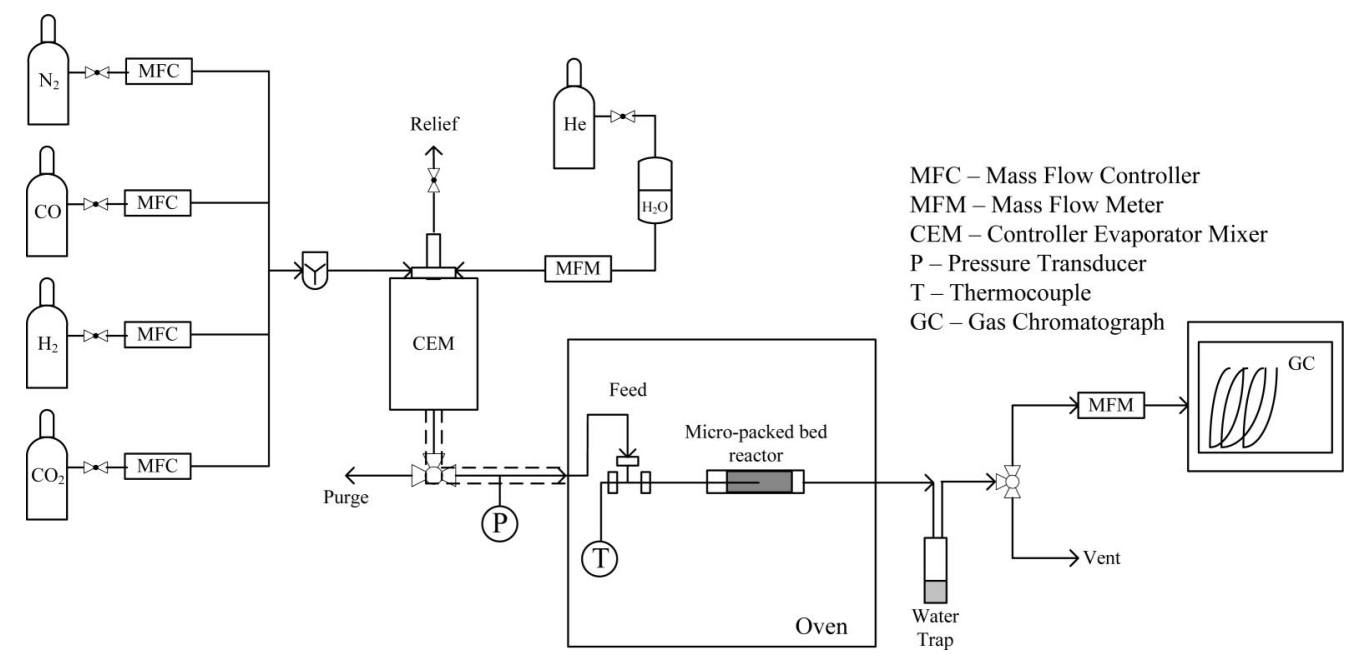

Figure 1. Sketch of the experimental setup.

and the reactor was flushed with $\mathrm{N}_{2}$ prior to the introduction of the reaction mixture. To avoid overheating of the catalyst bed and subsequent metal particle sintering, strict temperature and hydrogen flow rate controls were performed.

The reaction was started by introducing, for instance, a typical reforming gas mixture of $4.70 \% \mathrm{CO}, 34.78 \% \mathrm{H}_{2} \mathrm{O}, 28.70 \% \mathrm{H}_{2}$, $10.16 \% \mathrm{CO}_{2}$, and $21.66 \% \mathrm{~N}_{2}$ (vol \%) in the reactor feed, using four mass flow controllers (cf. Figure 1). Deionized water was metered, vaporized, and mixed in a controller evaporator mixer (CEM; Bronkorst) system with the other gases before entering the reactor. The GHSV (gas hourly space velocity) was fixed at $4800 \mathrm{~mL} \cdot \mathrm{g}_{\text {cat }}{ }^{-1} \cdot \mathrm{h}^{-1}$ and the reaction temperature varied between 150 and $300^{\circ} \mathrm{C}$. The reactor outlet stream was passed through a condenser to remove water for further analysis. The gas-phase products were then analyzed in an online gas chromatograph (Dani $1000 \mathrm{GC}$ ). A chromatographic column (Supelco Carboxen 1010 plot, from Sigma-Aldrich, $30 \mathrm{~m} \times$ $0.32 \mathrm{~mm}$ i.d.), with $\mathrm{He}$ as the carrier gas $\left(1 \mathrm{~mL}_{\mathrm{N}} \mathrm{min}^{-1}\right)$ and a TCD (Valco thermal conductivity detector), was used to analyze $\mathrm{N}_{2}, \mathrm{CO}$, and $\mathrm{CO}_{2}$. The carbon and the nitrogen molar balance relative errors were typically lower than $10 \%$. Regarding hydrogen, it is well-known that it is difficult to measure its composition by $\mathrm{GC}$ with the used detector since its thermal conductivity is close to that of helium, the carrier gas. Therefore, the $\mathrm{H}_{2}$ composition in the gas streams was calculated from the mass balance (difference from $100 \%$, dry basis), which is required for mass flow rate corrections. During the analysis, a temperature program was used as follows: (i) isothermal operation at $35{ }^{\circ} \mathrm{C}$ for $7.5 \mathrm{~min}$; (ii) heating from 35 to $80^{\circ} \mathrm{C}$ with a rate of $10{ }^{\circ} \mathrm{C} \cdot \mathrm{min}^{-1}$; (iii) keeping the sample at $80^{\circ} \mathrm{C}$ for $8 \mathrm{~min}$. All the pipes and valves along the water feed stream and in the reactor exit were heated to $130{ }^{\circ} \mathrm{C}$ to prevent the condensation of water.

\section{Results and Discussion}

3.1. Characterization of the Samples. The structural and morphological properties of the samples used in this work were first investigated. The metal loading (in the case of copper samples, this refers to the oxide form), the surface areas of the formulations, and the average size of the metal particles, as estimated by the HRTEM technique, are given in Table 1 .

As illustrated in Figure 2, spherical copper particles homogeneously distributed on the respective surface were obtained for the $\mathrm{CuO} / \mathrm{Al}_{2} \mathrm{O}_{3}$ sample, for which HRTEM results indicate an average size of around $9.2 \mathrm{~nm}$ (cf. Table 1). The low copper

Table 1. Physical Properties of the Studied Samples

\begin{tabular}{lccc}
\hline \multicolumn{1}{c}{ sample } & $\begin{array}{c}\text { active metal } \\
\text { loading (wt \%) }\end{array}$ & $\begin{array}{c}S_{\text {BET }} \\
\left(\mathrm{m}^{2} / \mathrm{g}\right)\end{array}$ & $\begin{array}{c}\text { av metal particle } \\
\text { size }(\mathrm{nm})\end{array}$ \\
\hline $\mathrm{CuO} / \mathrm{Al}_{2} \mathrm{O}_{3}$ & $5-20^{a}$ & 110 & 9.2 \\
$\mathrm{CuO} / \mathrm{ZnO} / \mathrm{Al}_{2} \mathrm{O}_{3}$ & $\sim 50^{a}$ & 9.0 & 6.9 \\
$\mathrm{Au} / \mathrm{TiO}_{2}$ & $1.5^{a}$ & 37 & 4.0 \\
$\mathrm{Au} / \mathrm{CeO}_{2}$ & 1.5 & 180 & $4.4^{b}$
\end{tabular}

${ }^{a}$ Data given by the manufacturer. ${ }^{b} \mathrm{~A}$ total of 200 particles were counted, due to the poor contrast between gold and ceria.
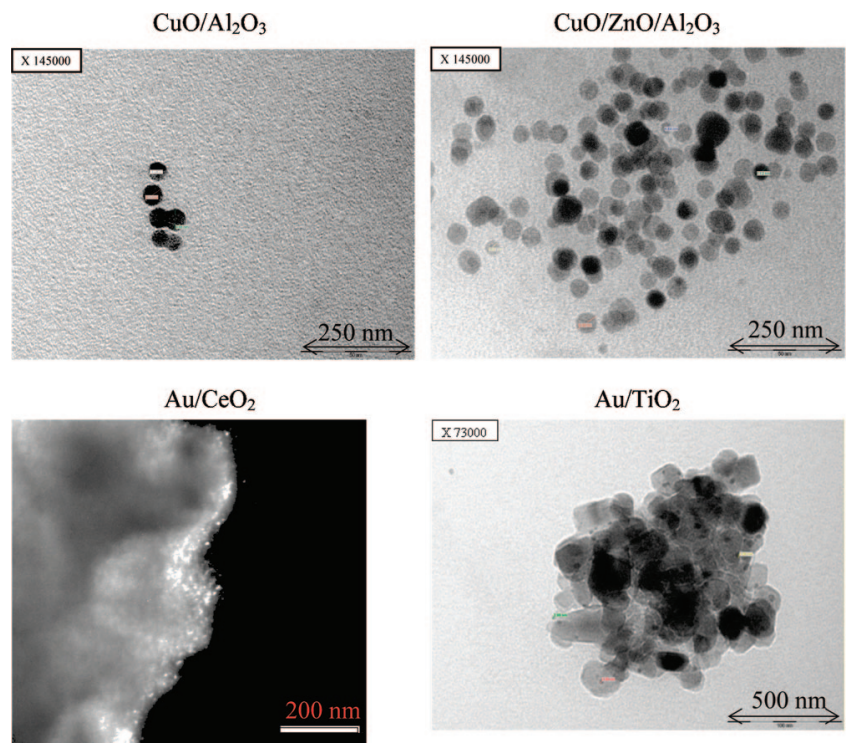

Figure 2. TEM pictures of the catalyst samples studied.

content in this catalyst is evident in the picture since only a little aggregation is seen. For the $\mathrm{CuO} / \mathrm{ZnO} / \mathrm{Al}_{2} \mathrm{O}_{3}$ solid the smaller particle size and the higher copper loading are perceptively presented in the picture since a higher density of $\mathrm{CuO}$ particles (aggregation) is seen (Figure 2). This also occurs for the Au-based catalysts, in which the particle size is even smaller, being particularly noticed for the $\mathrm{Au} / \mathrm{TiO}_{2}$ sample. HRTEM was used to report the size of gold nanoparticles. Therefore, the gold nanoparticles have been identified by the fringe distance shown in Figure 3 that corresponds to the gold interatomic distance.

The catalysts were also studied by Raman spectroscopy (Figure 4). In the case of $\mathrm{CuO} / \mathrm{Al}_{2} \mathrm{O}_{3}$ no peaks were recorded, probably due to the strong fluorescence of the material. In contrast, for $\mathrm{CuO} / \mathrm{ZnO} / \mathrm{Al}_{2} \mathrm{O}_{3}$ and $\mathrm{Au} / \mathrm{CeO}_{2}$ the peaks charac- 


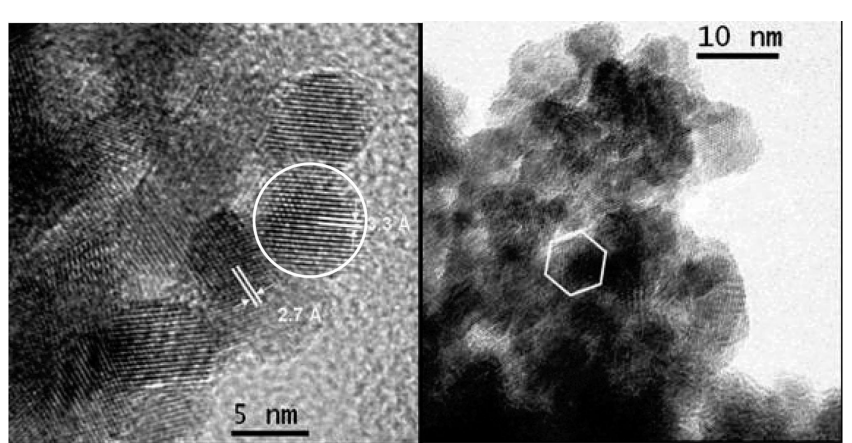

Figure 3. HRTEM picture of the $\mathrm{Au} / \mathrm{CeO}_{2}$ catalyst.

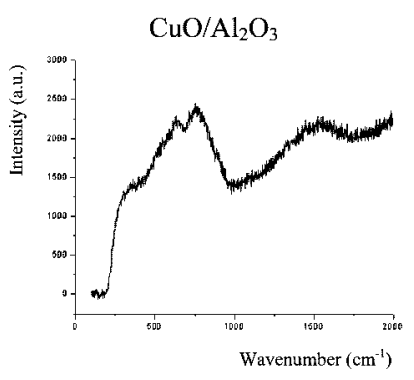

$\mathrm{Au} / \mathrm{CeO}_{2}$

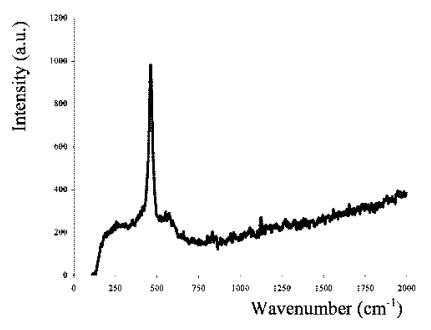

$\mathrm{CuO} / \mathrm{ZnO} / \mathrm{Al}_{2} \mathrm{O}_{3}$

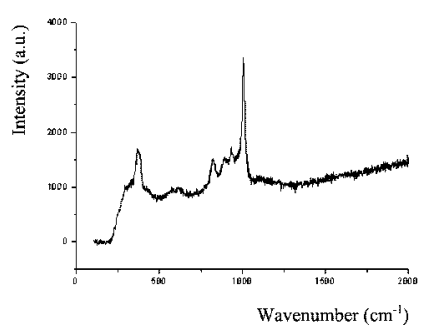

$\mathrm{Au} / \mathrm{TiO}_{2}$

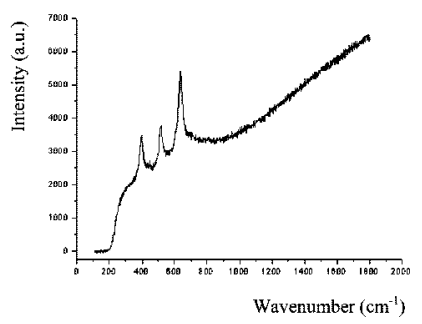

Figure 4. Raman spectra of the catalysts studied in this work.

teristic of $\mathrm{ZnO}\left(380 \mathrm{~cm}^{-1}\right)$ and $\mathrm{CeO}_{2}\left(475 \mathrm{~cm}^{-1}\right)$ were observed. In the latter sample, the observed peak corresponds to the $\mathrm{Ce}-\mathrm{O}$ vibration bond. The $\mathrm{Au}-\mathrm{Au}$ vibration appears below $200 \mathrm{~cm}^{-1}$ and is not visible due to the low loading of the materials and the low intensity of the peak. From the $\mathrm{Au} / \mathrm{TiO}_{2}$ Raman spectrum it can also be concluded that titanium dioxide is predominantly constituted by the anatase phase (due to the wellknown $\mathrm{TiO}_{2}$ anatase bands at 398, 516, and $640 \mathrm{~cm}^{-1}$ ).

The TPR technique was used to evaluate the reducibility of the synthesized sample, before and after Au addition to the ceria support. The redox characteristics of this type of catalyst are known to be relevant for their performance in the WGS reaction. Comparison of the TPR profiles of $\mathrm{CeO}_{2}$ and $\mathrm{Au} / \mathrm{CeO}_{2}$ clearly reveals that the presence of gold nanoparticles on the surface of the ceria support exerts a remarkable influence, favoring the reducibility of this metal oxide (Figure 5). Thus, the reduction peak that appears at about $470{ }^{\circ} \mathrm{C}$ in $\mathrm{CeO}_{2}$ becomes considerably shifted to much lower temperatures (about $95{ }^{\circ} \mathrm{C}$ ) when gold nanoparticles are present in the solid. The peak in the TPR profile at $63{ }^{\circ} \mathrm{C}$ is most probably related to the reduction of oxygen species, adsorbed during calcination in air, on some nanogold particles smaller than $2 \mathrm{~nm}$, in accordance with Boccuzzi et al. ${ }^{24}$ In conclusion, Figure 5 shows the reducibility increase of the $\mathrm{Au} / \mathrm{CeO}_{2}$ sample with the TPR promotional effect of gold on the surface reduction of ceria, leading to the creation of oxygen vacancies. Therefore, the gold particles located in close contact with these oxygen-vacancy defects of ceria may be very active sites for WGS reaction.

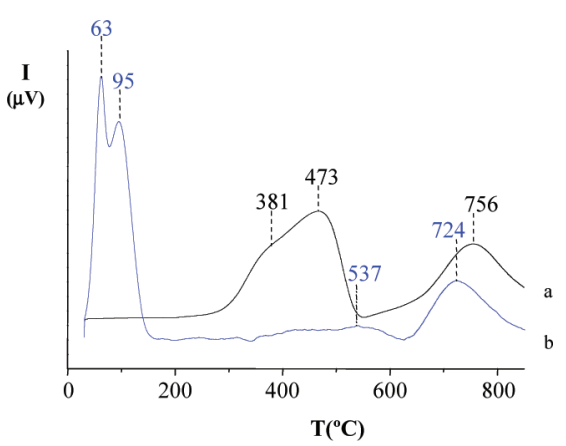

Figure 5. Temperature-programmed reduction by hydrogen of $\mathrm{CeO}_{2}$ (a) and $\mathrm{Au} / \mathrm{CeO}_{2}$ (b).

3.2. Catalytic Tests. In this section the catalytic performance of $\mathrm{Au} / \mathrm{CeO}_{2}$ toward the WGS reaction is compared with that of three commercial catalysts: (i) $\mathrm{Au} / \mathrm{TiO}_{2}$, purchased from the World Gold Council and which has the same Au content and a similar average particle size (cf. Table 1); (ii) the commercial $\mathrm{CuO} / \mathrm{Al}_{2} \mathrm{O}_{3}$ (CU-1271, Selectra shift) received from BASF; (iii) the commercial $\mathrm{CuO} / \mathrm{ZnO} / \mathrm{Al}_{2} \mathrm{O}_{3}$ purchased from REB Research $\&$ Consulting. The catalytic tests started by performing experiments using two different feeds: one with just $\mathrm{CO}$ and $\mathrm{H}_{2} \mathrm{O}$ (diluted in $\mathrm{He}$ ) and the other with a typical reformate composition $\left(4.70 \% \mathrm{CO}+34.78 \% \mathrm{H}_{2} \mathrm{O}+28.70 \% \mathrm{H}_{2}+10.16 \% \mathrm{CO}_{2}\right.$ $+21.66 \% \mathrm{~N}_{2}$ ). The effects of $\mathrm{H}_{2} \mathrm{O}$ and $\mathrm{CO}$ concentration in the feed are also important to analyze, and this was therefore done for each catalyst, at different temperatures. Data presented below concern the steady state (each data point in the graphs results from the average of at least three analyses; the maximum standard deviation obtained was $1.5 \%$ ) with the exception of the $\mathrm{Au} / \mathrm{CeO}_{2}$ sample, because in this case some catalyst deactivation was observed (see section 3.2.4 regarding stability tests). For this reason the activity measurements for this sample began at high temperatures (in which deactivation is negligible) and ended at low temperatures, the $\mathrm{CO}$ conversion being measured in the first $10000 \mathrm{~s}$ until a relative error below ca. $5 \%$ was obtained, in three consecutive analyses. During the night, the catalysts being tested were under a $\mathrm{N}_{2}$ atmosphere to avoid reoxidation.

3.2.1. Effect of Reaction Products in the Feed Composition. Figure 6 illustrates the effect of the reaction products $\left(\mathrm{H}_{2}\right.$ and $\mathrm{CO}_{2}$ ) on the performance attained by each catalytic system at different temperatures. As expected, the $\mathrm{CO}$ conversion increases with the reaction temperature due to the kinetic constraints, in some cases approaching the thermodynamic equilibrium conversion (dashed lines in the figures). After this point, the conversion decreases due to the exothermic nature of the reaction. The equilibrium conversion $\left(X_{\mathrm{CO} \text {,eq }}\right)$ values were calculated on the basis of the equilibrium constant $\left(K_{\mathrm{p}}=\right.$ $\exp [(4577.8 / T)-4.33]$, where $T$ is in kelvin) obtained by Moe. ${ }^{25}$ Assuming ideal gas behavior, the equilibrium conversion was then obtained by solving the following equation, where $K_{\mathrm{p}}$ is expressed on the basis of the feed composition ( $y_{i, \text { in }}$ refers to the molar fraction of species $i$ at the reactor inlet):

$$
K_{\mathrm{p}}=\frac{\left(y_{\mathrm{CO}_{2}, \text { in }}+y_{\mathrm{CO}, \text { in }} X_{\mathrm{CO}, \text { eq }}\right)\left(y_{\mathrm{H}_{2}, \text { in }}+y_{\mathrm{CO}, \text { in }} X_{\mathrm{CO}, \mathrm{eq}}\right)}{\left(y_{\mathrm{CO}, \text { in }}\left(1-X_{\mathrm{CO}, \mathrm{eq}}\right)\right)\left(y_{\mathrm{H}_{2} \mathrm{O}, \mathrm{in}}-y_{\mathrm{CO}, \text { in }} X_{\mathrm{CO}, \mathrm{eq}}\right)}
$$

Under only $\mathrm{CO}$ and water in helium, catalysts $\mathrm{CuO} / \mathrm{Al}_{2} \mathrm{O}_{3}$, $\mathrm{CuO} / \mathrm{ZnO} / \mathrm{Al}_{2} \mathrm{O}_{3}$, and $\mathrm{Au} / \mathrm{CeO}_{2}$ reveal a similar $\mathrm{CO}$ conversion that is higher than that reached by the $\mathrm{Au} / \mathrm{TiO}_{2}$ sample in the entire range of temperature tested (Figure 6). At $150{ }^{\circ} \mathrm{C}$ and for the first group of catalysts, the $\mathrm{CO}$ conversion reached is 

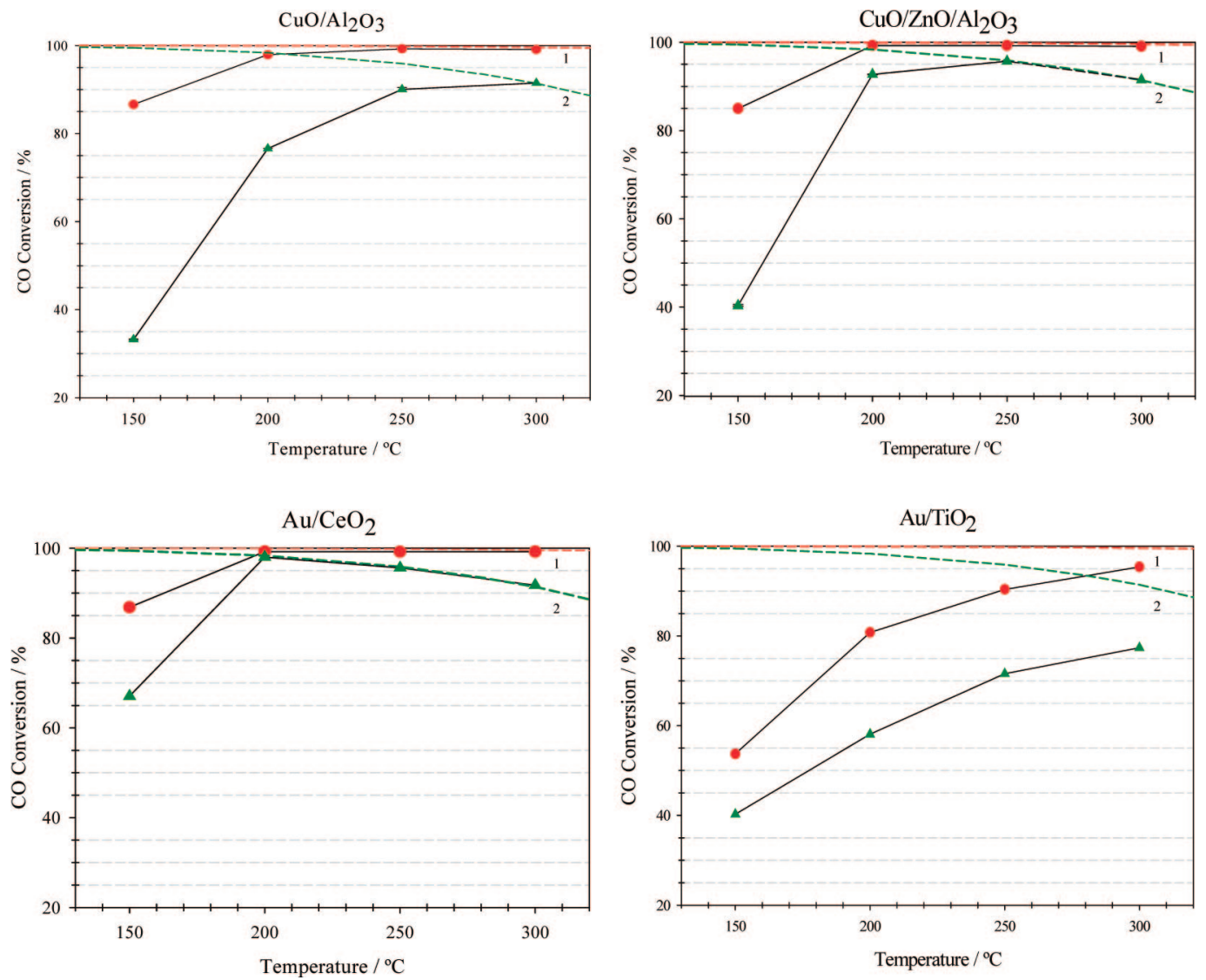

Figure 6. Effect of reaction products in the feed stream over the $\mathrm{CO}$ conversion for each catalyst at different temperatures. The lines represent the thermodynamic conversion. Feed composition: $(\bullet, 1) 4.74 \% \mathrm{CO}+35.39 \% \mathrm{H}_{2} \mathrm{O}+59.87 \% \mathrm{He},(\boldsymbol{\bullet}, 2) 4.74 \% \mathrm{CO}+35.39 \% \mathrm{H}_{2} \mathrm{O}+28.46 \% \mathrm{H}_{2}+10.06 \% \mathrm{CO}_{2}+21.35 \%$ $\mathrm{N}_{2}$.

similar and approximately $86 \%$, although for the $\mathrm{Au} / \mathrm{CeO}_{2}$ formulation this value is already affected by some deactivation noticed at low temperatures (cf. section 3.2.4 about stability tests). At higher temperatures the $\mathrm{CO}$ conversions tend to that predicted by the thermodynamics, but are always higher than that exhibited by the $\mathrm{Au} / \mathrm{TiO}_{2}$ catalyst.

The detrimental effect of $\mathrm{H}_{2}$ and $\mathrm{CO}_{2}$ in the feed stream is clearly noted in all the catalysts tested, in agreement with Le Chatelier's principle (reaction equilibrium shifts in the opposite direction, toward reactant formation, decreasing $\mathrm{CO}$ conversion). Several authors use empirical power law models to fit the kinetic data. Most of them show the negative effect of the presence of one or both reaction products. ${ }^{26-28}$ In our case, the major difference was obtained for the $\mathrm{CuO} / \mathrm{Al}_{2} \mathrm{O}_{3}$ sample at $150{ }^{\circ} \mathrm{C}$, reaching a $\mathrm{CO}$ conversion of only $33 \%$ when the reaction products are present in the reactor feed, compared with $87 \%$ in their absence. At $150{ }^{\circ} \mathrm{C}$ both $\mathrm{Cu}$-based catalysts are shown to be strongly affected by the presence of $\mathrm{CO}_{2}$ and $\mathrm{H}_{2}$. However, this drawback seems to be attenuated with the temperature increase. The presence of $\mathrm{ZnO}$ seems to be important in terms of the performance reached, i.e., in terms of tolerance to the presence of hydrogen and carbon dioxide. It is worth noting that the role of $\mathrm{ZnO}$ and $\mathrm{Al}_{2} \mathrm{O}_{3}$ regarding the WGS activity and the nature of the active sites for copper-based catalysts is still controversial. Besides their role as structural promoters, ${ }^{29-32}$ both oxides gathered some literature support working also as chemical promoters. In fact, several authors observed an enhancement in the catalytic activity of $\mathrm{Cu}$ supported on $\mathrm{ZnO}$ due to synergetic effects responsible for improved covalency between the different oxidation states of copper in the metal lattice. ${ }^{2,33-35}$ Moreover, the catalytic performance improvement from binary $\mathrm{CuO} / \mathrm{ZnO}$ to ternary $\mathrm{CuO} / \mathrm{ZnO} / \mathrm{Al}_{2} \mathrm{O}_{3}$ catalysts reveals the effect of adding alumina; alumina is reported to form a hydrotalcite phase that improves the catalyst performance. ${ }^{22}$ On the other hand, the lower copper loading in the $\mathrm{CuO} / \mathrm{Al}_{2} \mathrm{O}_{3}$ catalyst (see Table 1) might influence the lower CO conversion obtained with this sample.

Under the operating conditions of Figure 6, the $\mathrm{Au} / \mathrm{CeO}_{2}$ sample shows the best performance. It is known that, for $\mathrm{Au}-$ based catalysts, the synthesis method (which was the same for both samples-deposition/precipitation) and corresponding conditions affect their WGS performance. Nevertheless, the influence of the gold support (ceria or titania) may have a major role in terms of their activity. As succeeds with $\mathrm{Cu}$-based catalysts, many authors believe that the WGS reaction on supported noble materials, namely, on reducible metal oxides $\left(\mathrm{CeO}_{2}, \mathrm{TiO}_{2}, \mathrm{ZrO}_{2}, \ldots\right)$, is a bifunctional system too. The reaction mechanism is assumed to be conducted in two different sites: the dispersed metallic phase, which is mainly responsible for adsorption/activation of $\mathrm{CO}$, and the metal oxide support, which is hydrophilic in nature and is mainly responsible for adsorption/ activation of $\mathrm{H}_{2} \mathrm{O} .{ }^{36-38}$ Both ceria and titania have the capacity to be reduced under the WGS reaction conditions. Several authors refer to the reducibility of the support as being an important key to a higher catalyst activity due to the formation of either oxygen vacancies within the support or partially reduced sites at the metal-support interface. ${ }^{17,37-40}$ Thus, the higher WGS activity obtained with the ceria-supported catalyst can be due to its higher redox capacity and mobility of the surface oxygen/hydroxyl group when compared with the titaniasupported catalyst. Indeed, Idakiev et al. ${ }^{41}$ also found a shift of the TPR peak to low temperatures after incorporation of $\mathrm{Au}$ in 

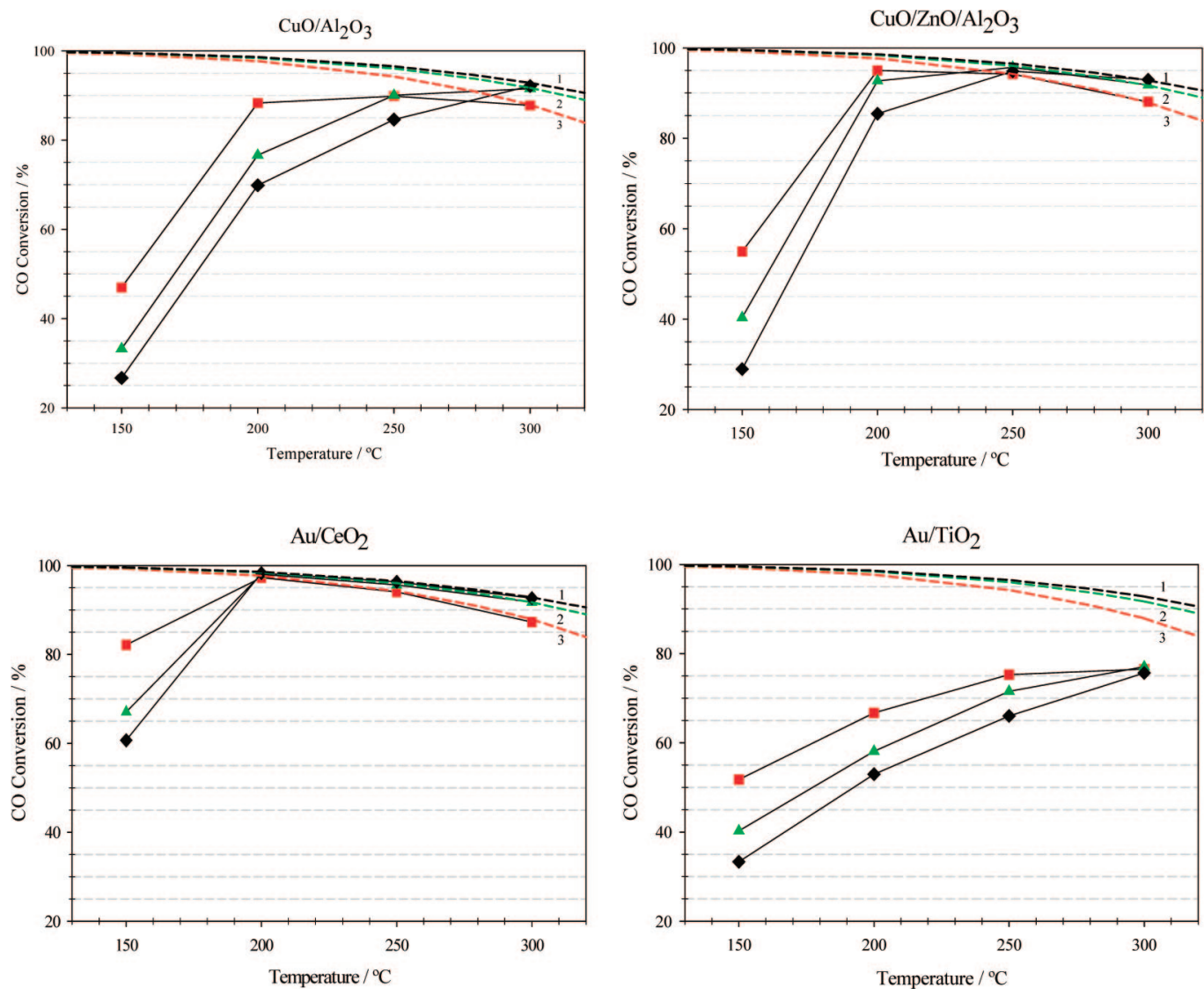

Figure 7. Effect of the $\mathrm{CO}$ content in the feed stream composition over the $\mathrm{CO}$ conversion for each catalyst at different temperatures. The lines represent the thermodynamic conversion. Feed composition: $(\bullet, 1) 9.42 \% \mathrm{CO},(\boldsymbol{\Delta}, 2) 4.74 \% \mathrm{CO},(\boldsymbol{\square}, 3) 2.38 \% \mathrm{CO}$. In all cases the rest of the feed is $35.39 \% \mathrm{H}_{2} \mathrm{O}$, $28.46 \% \mathrm{H}_{2}, 10.06 \% \mathrm{CO}_{2}$, and the balance $\mathrm{N}_{2}$.

$\mathrm{TiO}_{2}$ (from 400 to $100{ }^{\circ} \mathrm{C}$ ), but the intensity of such a lowtemperature peak is almost negligible compared to that of the original support, in opposition to what happens for the $\mathrm{Au} / \mathrm{CeO}_{2}$ sample (see section 3.1). Finally, the higher surface area of the ceria support, also responsible for a better metal dispersion, is certainly an important parameter for the activity enhancement attained.

3.2.2. Effect of the CO Content in the Feed. The effect of the $\mathrm{CO}$ content in the feed stream is also important to analyze due to the inherent implications on the thermodynamic equilibrium. In addition, this also allows to study the performance of WGS catalysts under different feed compositions as happens when the WGS feed proceeds from different steam-reforming processes and hydrocarbon feedstocks. The effect of the $\mathrm{CO}$ concentration on the conversion is illustrated in Figure 7.

The $\mathrm{CO}$ concentration decrease in the gas feed produces an increase in the performance of all catalysts, at least at $150{ }^{\circ} \mathrm{C}$. This behavior seems to be not consistent with that predicted by Le Chatelier's principle, but is also observed in other works. ${ }^{19,27}$ Amadeo and Laborde ${ }^{27}$ studied the influence of the partial pressure of the WGS reactants and products on the $\mathrm{CO}$ conversion over a copper-based commercial catalyst at $503 \mathrm{~K}$. The authors justified the observed negative effect by the proportional formation of $\mathrm{CO}_{2}$ when the feed $\mathrm{CO}$ partial pressure increases. In the work by Luengnaruemitchai et al., ${ }^{19}$ the effect of $\mathrm{CO}$ and $\mathrm{H}_{2} \mathrm{O}$ concentrations over the catalytic performance of $\mathrm{Au} / \mathrm{CeO}_{2}$ was studied, with an idealized feed consisting of $0.5-2 \% \mathrm{CO}$ and $2.6 \% \mathrm{H}_{2} \mathrm{O}$ in helium. However, no explanation was given for the negative effect of the increasing $\mathrm{CO}$ concentration for this catalytic system. Nevertheless, as the temperature increases the catalytic systems tested in this work tend to create a "zone" where the effect of the $\mathrm{CO}$ concentration on the catalytic performance is less significant, revealing that its effect on the conversion can change with the reaction temperature (Figure 7). However, this zone is located at different temperatures, according to the higher or lower catalyst activity. Beyond that region, the data tend to follow the equilibrium conversion lines, as predicted by Le Chatelier's principle (the conversion is higher for higher $\mathrm{CO}$ contents in the reactant feed, because this shifts the equilibrium).

For Cu-based WGS catalysts different reaction orders regarding $\mathrm{CO}$ concentration have been reported. For instance, Ayastuy et al. ${ }^{26}$ and Ovesen et al. ${ }^{28}$ reported a unity order of reaction with respect to $\mathrm{CO}$ over ternary $\mathrm{Cu}$-based catalysts. On the other hand, Salmi and Hakkaraine ${ }^{42}$ reported variable $\mathrm{CO}$ reaction orders as a function of temperature, ranging from 1 to 0.45 . For $\mathrm{Au} / \mathrm{CeO}_{2}$ catalysts Leppelt et al. ${ }^{23}$ reported a $\mathrm{CO}$ reaction order of 0.5. In fact, for all WGS catalysts studied the CO positive reaction order is verified only above a certain temperature. The negative (retardation) effect observed in this work for both $\mathrm{Cu}$ and $\mathrm{Au}$ catalysts at lower temperatures can be explained on the basis of the associative mechanism, namely, on the intermediate species (formates and/or carbonates) formed during the reaction. Once the $\mathrm{CO}$ concentration increases, the formation of intermediate species also increases. At lower temperatures, the coverage of this species over the catalyst surface increases for both copper-based ${ }^{43}$ and gold-based ${ }^{44}$ catalysts due to a slower decomposition of these intermediates into the final reaction products. Therefore, a blocking effect of the active sites by the reaction intermediates, which is more severe at lower temperatures, should happen, decreasing the overall CO conversion; this is also behind the deactivation 

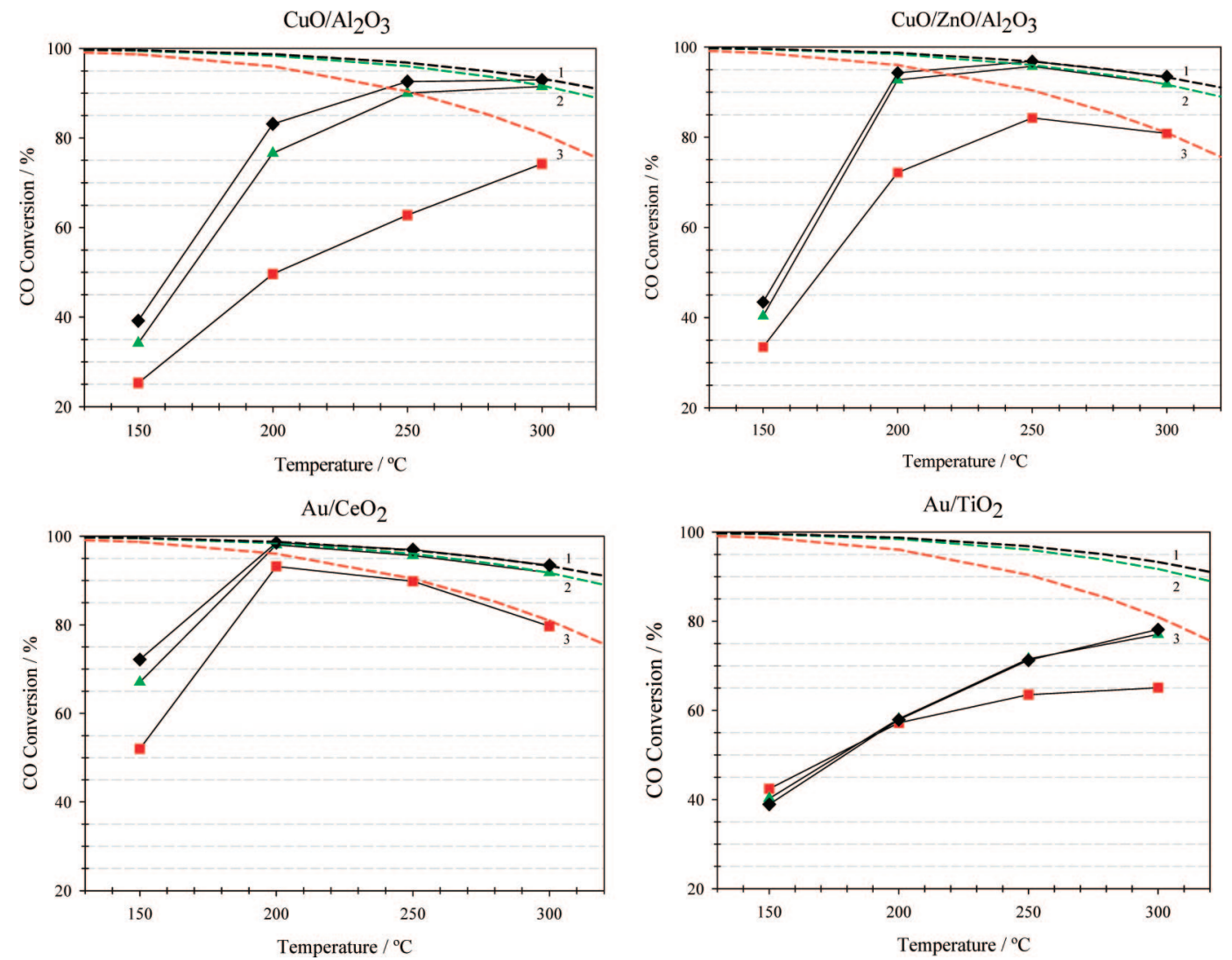

Figure 8. Effect of $\mathrm{H}_{2} \mathrm{O}$ content in the feed stream composition over the $\mathrm{CO}$ conversion for each catalyst at different temperatures. The lines represent the thermodynamic conversion. Feed composition: $(\bullet, 1) 43.74 \% \mathrm{H}_{2} \mathrm{O},(\boldsymbol{\Delta}, 2) 35.39 \% \mathrm{H}_{2} \mathrm{O},(\boldsymbol{\square}, 3) 16.90 \% \mathrm{H}_{2} \mathrm{O}$. In all cases the rest of the feed is $4.74 \% \mathrm{CO}$, $28.46 \% \mathrm{H}_{2}, 10.06 \% \mathrm{CO}_{2}$, and the balance $\mathrm{N}_{2}$.

observed for the $\mathrm{Au} / \mathrm{CeO}_{2}$ catalyst at lower temperatures (section 3.2.4). The decomposition of formates and/or carbonates is favored by the temperature increase, the $\mathrm{CO}$ conversion being no longer negatively affected by the $\mathrm{CO}$ partial pressure (in most cases it is inclusively positively affected). The temperature range of this transition clearly depends on the performance of each catalytic system. It is therefore important that the usage of empirical power rate laws available in the literature takes into account the temperature range (and other operating conditions) in which the experiments are performed.

The Cu-based catalysts used in this study presented a similar behavior, where the apparent negative order dependence on $\mathrm{CO}$ happens in the same temperature range. However, for the $\mathrm{Au}-$ based catalysts this does not happen. From Figure 7 it is clear that, for the $\mathrm{Au} / \mathrm{TiO}_{2}$ sample, no positive order dependence on $\mathrm{CO}$ was attained in the used range of temperatures. On the other hand, for the $\mathrm{Au} / \mathrm{CeO}_{2}$ sample the positive effect was reached at around $200{ }^{\circ} \mathrm{C}$. Assuming the above-mentioned catalyst's bifunctionality, it is found that the supports responsible for the $\mathrm{H}_{2} \mathrm{O}$ activation can be responsible for this difference. As referred to above, the synergistic effects between gold (where $\mathrm{CO}$ is adsorbed) and titania are lower than with ceria; therefore, in the latter the formation of intermediate hydroxyl groups (via adsorbed water) is not limiting, so higher $\mathrm{CO}$ contents are favorable for a higher activity.

The ceria-supported gold catalyst is, once again, the one that seems to be more promising because it is considerably active and less affected by the $\mathrm{CO}$ concentration, at least at low temperatures $\left(150-200{ }^{\circ} \mathrm{C}\right)$. At high temperatures $\left(250-300{ }^{\circ} \mathrm{C}\right) \mathrm{CuO} / \mathrm{ZnO} / \mathrm{Al}_{2} \mathrm{O}_{3}$ exhibits a similar performance. $\mathrm{Au} / \mathrm{TiO}_{2}$ is the worst sample, also in agreement with the data of Figure 6.
3.2.3. Effect of the $\mathrm{H}_{2} \mathrm{O}$ Content in the Feed. The dependence of the catalysts' performances on the water vapor concentration in the feed stream was also analyzed. It is clearly seen from Figure 8 that, in general, the water vapor content enhances the catalysts' performance in the temperature range $150-300{ }^{\circ} \mathrm{C}$, in agreement with the thermodynamic prediction. This fact is also in agreement with the positive reaction order with respect to water obtained in power law rates. ${ }^{23,26-28,42}$

For the $\mathrm{Au} / \mathrm{TiO}_{2}$ sample the activity results in the temperature range $150-200{ }^{\circ} \mathrm{C}$ are not influenced by the water vapor content. For higher temperatures the increase in the water vapor content above $35.39 \%(\mathrm{v} / \mathrm{v})$ does not bring any change in the $\mathrm{CO}$ conversion, clearly opposed to what happens with the other catalysts. Once again the influence of the support is clearly noticed. The $\mathrm{Au} / \mathrm{CeO}_{2}$ catalyst revealed to be, in terms of catalytic performance, the most promising one since no significant changes were detected with the water vapor concentration, and above $200{ }^{\circ} \mathrm{C}$ the conversion reaches the thermodynamic one. It seems therefore that the interaction between gold and ceria, which was highlighted by TPR, results in an activity enhancement. Actually, Rodriguez et al. ${ }^{45}$ pointed out very recently that the noble metal nanoparticles promote the partial reduction of the ceria support by $\mathrm{CO}$ or $\mathrm{CO} / \mathrm{H}_{2} \mathrm{O}$ mixtures, creating in ceria surface oxygen vacancies where the $\mathrm{H}_{2} \mathrm{O}$ activation takes place. This evidence corroborates the preview studies by Tabakova et al., ${ }^{46}$ who have used FTIR spectroscopy to find experimental evidence for modification of ceria in the presence of gold and the appearance of oxygen vacancies at the ceria surface after reduction with hydrogen. The authors stressed the importance of oxygen vacancies and showed that the WGS reaction proceeds at the boundary between small 

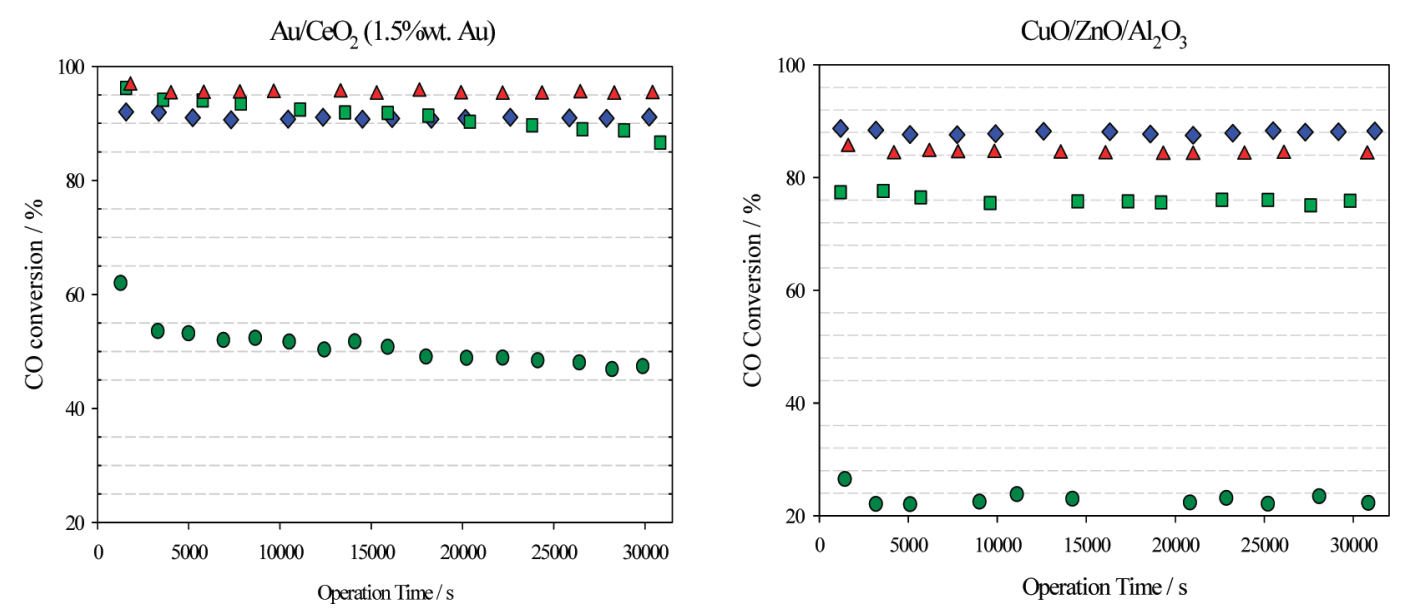

Figure 9. Effect of the time on stream in the WGS activity at different temperatures. Feed composition: $4.74 \% \mathrm{CO}+35.39 \% \mathrm{H}_{2} \mathrm{O}+28.46 \% \mathrm{H}_{2}+10.06 \%$ $\mathrm{CO}_{2}+21.35 \% \mathrm{~N}_{2}$. Temperature: (४) $300{ }^{\circ} \mathrm{C},(\boldsymbol{\Delta}) 250{ }^{\circ} \mathrm{C}$, (৫) $200{ }^{\circ} \mathrm{C},(\bullet) 150{ }^{\circ} \mathrm{C}$.

metallic gold particles and ceria, where $\mathrm{CO}$ adsorption on gold and $\mathrm{H}_{2} \mathrm{O}$ dissociation on ceria defects take place. The difference in the support reducibility, as well as its capacity to allow the formation of $\mathrm{OH}$ groups, might be the responsible for the distinct behavior observed in the WGS activity of the two Au-based catalysts, when the water vapor concentration is changed.

In the literature it is reported that the water content is crucial for the $\mathrm{CO}$ conversion performance of a commercial $\mathrm{CuO} / \mathrm{ZnO}$ catalyst ${ }^{22}$ in agreement with our results (Figure 8). Comparing both $\mathrm{Cu}$-based catalysts, it can be seen that the $\mathrm{CuO} / \mathrm{ZnO} / \mathrm{Al}_{2} \mathrm{O}_{3}$ catalyst is less influenced by the $\mathrm{H}_{2} \mathrm{O}$ concentration. This fact can be connected with the different structures of the $\mathrm{Cu}$ particles in each catalyst, described as a possible site for $\mathrm{H}_{2} \mathrm{O}$ activation. ${ }^{45}$ However, taking into account the catalyst bifunctionality suggested by Grenoble et al., ${ }^{36}$ we may conclude that the support oxide sites are close to the maximum capacity to activate the water vapor. The $\mathrm{CuO} / \mathrm{ZnO} / \mathrm{Al}_{2} \mathrm{O}_{3}$ sample exhibits, once again, higher $\mathrm{CO}$ conversion than the $\mathrm{CuO} / \mathrm{Al}_{2} \mathrm{O}_{3}$ sample.

3.2.4. Deactivation Tests. An important issue to take into account for the industrial application of any catalyst in hydrogen fuel processing is its stability under WGS conditions. WGS copper-based catalysts are known to be highly stable; however, the gold-based ones, particularly when supported in ceria, have been subjected to extensive work to understand and overcome this problem. Generally, four issues have been widely discussed: (1) the sintering of the metal particles, ${ }^{19,47}$ (2) the "irreversible" over-reduction of the ceria support, ${ }^{5}(3)$ the loss of surface area of ceria, ${ }^{11,20}$ and (4) the blocking of the ceria surface by formation of surface carbonates and/or formates. ${ }^{44,48,49}$

The two most promising catalysts of this study were then evaluated in terms of their stability. The CO conversion levels were measured at different temperatures after reduction of the samples, and the results are shown in Figure 9. It can be seen that the $\mathrm{CuO} / \mathrm{ZnO} / \mathrm{Al}_{2} \mathrm{O}_{3}$ catalyst showed a better stability than $\mathrm{Au} / \mathrm{CeO}_{2}$ under the WGS reaction conditions. $\mathrm{CuO} / \mathrm{ZnO}$ formulations are known to be deactivated by thermal sintering and/ or poisoning of the catalyst surface at temperatures above 300 ${ }^{\circ} \mathrm{C} .{ }^{7}$ In this case, under our experimental conditions, no signs of long-term deactivation were detected, even at $300{ }^{\circ} \mathrm{C}$, which is reported in the literature as being the maximum temperature to avoid the surface migration of the metal particles over the catalyst support. On the other hand, the catalytic activity of $\mathrm{Au} /$ $\mathrm{CeO}_{2}$ decreased progressively at temperatures of 150 and 200 ${ }^{\circ} \mathrm{C}$, remaining stable at higher temperatures (see Figure 9).

It is therefore clear that the deactivation of such a catalyst is strongly dependent on the temperature. Such deactivation of
$\mathrm{Au} / \mathrm{CeO}_{2}$ seems to be not consistent with literature references about sintering of the gold particles, because when temperature increases, changes in conversion with time are not detectable. It is not possible to establish which deactivation(s) mechanism(s) is/are present (this will be the aim of future work); however, a surface fouling might occur since, at lower temperatures, where the intermediates decomposition is slower, reaction species might block the catalyst sites and consequently decrease the $\mathrm{CO}$ conversion. With the temperature increase, the intermediates decomposition is accelerated and no deactivation happens. This idea is in line with the work by Jacobs et al., ${ }^{50}$ where it was concluded that formates are reaction intermediate species and that at higher temperatures their concentration is limited by the WGS reaction rate, while at lower temperatures the formate surface concentration remains close to the adsorption/desorption equilibrium. Karpenko and coauthors ${ }^{44}$ also justified the deactivation behavior at lower temperatures, now due to the formation of carbonates adsorbed on the ceria support, blocking the sites. Therefore, the carbonate decomposition rate is too low to keep the steady-state carbonate coverage at a low level, promoting the catalyst deactivation. The authors confirmed the carbonate formation, obtaining complete catalyst activity regeneration with an oxidation treatment.

A comparison test in terms of $\mathrm{CO}$ conversion obtained for gold/ceria catalysts with different Au loadings $(\sim 1.5$ and 2.5 wt $\%$ ) was then performed at $150{ }^{\circ} \mathrm{C}$. The results are presented in Figure 10.

For the catalyst with higher Au loading a higher $\mathrm{CO}$ conversion was obtained during the first $30000 \mathrm{~s}(\sim 8.3 \mathrm{~h})$. It is reported in the literature that the reaction rate of $\mathrm{Au} / \mathrm{CeO}_{2}$ catalysts varies as a volcano-type curve as a function of the gold metal loading. Maxima at $5 \mathrm{wt} \%^{23}$ and $3 \mathrm{wt} \%^{13}$ were reported. Nevertheless, Figure 10 shows also that the deactivation rate of this catalyst is higher than for the $1.5 \mathrm{wt} \% \mathrm{Au} /$ ceria catalyst. The activity of the lower Au loading catalyst seems to remain nearly constant, after ca. $20000 \mathrm{~s}(\sim 5.6 \mathrm{~h})$, a fact that can be explained by the adsorption/desorption equilibrium of carbonates and/or formates at the catalyst surface. The higher deactivation observed in the 2.5 wt \% Au/ceria catalyst might be due to the higher carbonate and/or formate concentration at the catalyst surface, formed at the beginning of the reaction as a consequence of its higher catalytic performance, leading thus to a higher surface coverage and promoting a stronger blocking effect. 


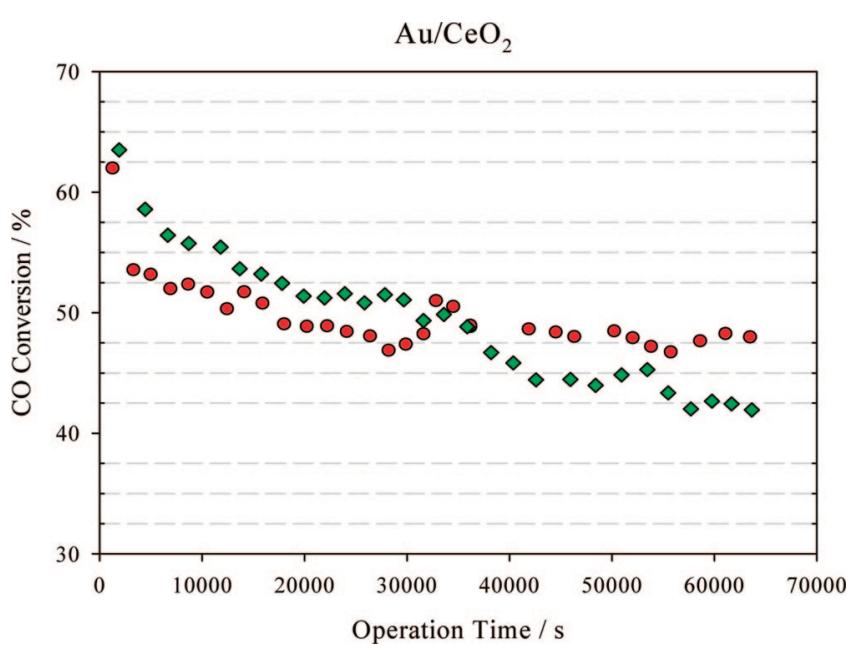

Figure 10. Effect of the operation time on the WGS activity, at $150{ }^{\circ} \mathrm{C}$, for $\mathrm{Au} / \mathrm{CeO}_{2}$ catalysts with different Au loadings. Feed composition: $4.74 \%$ $\mathrm{CO}+35.39 \% \mathrm{H}_{2} \mathrm{O}+28.46 \% \mathrm{H}_{2}+10.06 \% \mathrm{CO}_{2}+21.35 \% \mathrm{~N}_{2}$. Au loading: (•) $2.5 \mathrm{wt} \%,(\bullet) 1.5 \mathrm{wt} \%$.

\section{Conclusions}

The catalytic performance of $\mathrm{Au} / \mathrm{TiO}_{2}, \mathrm{Au} / \mathrm{CeO}_{2}, \mathrm{CuO} / \mathrm{Al}_{2} \mathrm{O}_{3}$, and $\mathrm{CuO} / \mathrm{ZnO} / \mathrm{Al}_{2} \mathrm{O}_{3}$ catalysts has been investigated for WGS reaction in the low temperature range. It was found that the presence of reaction products in the feed stream has a higher negative effect on $\mathrm{CO}$ conversion for $\mathrm{Cu}$-based catalysts when compared with the gold-based ones, namely, at $150{ }^{\circ} \mathrm{C}$. Under the reformate conditions $\left(4.74 \% \mathrm{CO}+35.39 \% \mathrm{H}_{2} \mathrm{O}+28.46 \%\right.$ $\mathrm{H}_{2}+10.06 \% \mathrm{CO}_{2}$, balance $\mathrm{N}_{2}$ ), the $\mathrm{Au} / \mathrm{CeO}_{2}$ sample is shown to be the most active (particularly at low temperatures, i.e., $\left.150-200{ }^{\circ} \mathrm{C}\right)$. The activity of gold/ceria indicates that the support plays an important role in this reaction catalysis. The commercial $\mathrm{CuO} / \mathrm{ZnO} / \mathrm{Al}_{2} \mathrm{O}_{3}$ catalyst showed the best relation of activity/stability. In addition, it was found that the $\mathrm{CO}$ concentration present in the reactor feed greatly affects the activity of all catalysts tested. Depending on the reaction temperature, this effect is negative or positive in terms of the catalyst's performance. We also observed that water had a positive effect on $\mathrm{CO}$ conversion for all the catalysts, except for the $\mathrm{Au} / \mathrm{TiO}_{2}$ catalyst.

The results of this study indicate that the catalyst selection has to take into account the operation reaction temperature range. At temperatures $\geq 250{ }^{\circ} \mathrm{C} \mathrm{Au} / \mathrm{CeO}_{2}$ is clearly a better option since it seems not to be affected by the deactivation mechanism and shows a higher $\mathrm{CO}$ conversion than $\mathrm{CuO} / \mathrm{ZnO} / \mathrm{Al}_{2} \mathrm{O}_{3}$. However, at lower temperatures, the stability is a negative factor for its selection and the latter seems to be a better option.

\section{Acknowledgment}

Diogo Mendes and Valter Silva are grateful to the Portuguese Foundation for Science and Technology (FCT) for their doctoral grants (SFRH/BD/22463/2005 and SFRH/BD/18159/2004, respectively). We also acknowledge financing from FCT through Projects POCTI/EQU/59345/2004 and PTDC/EQU/ERQ/66045/ 2006. Finally, we are most grateful to Dr. Oleg Ilinich (BASF) for providing the $\mathrm{CuO} / \mathrm{Al}_{2} \mathrm{O}_{3}$ sample.

\section{Literature Cited}

(1) Energy Information Administration. International Energy Outlook; U.S. Department of Energy: Washington, DC, 2007.

(2) Trimm, D. L.; Onsan, Z. I. Onboard fuel conversion for hydrogenfuel-cell-driven vehicles. Catal. Rev.-Sci. Eng. 2001, 43 (1-2), 31-84.
(3) Wee, J. H.; Lee, K. Y. Overview of the development of CO-tolerant anode electrocatalysts for proton-exchange membrane fuel cells. J. Power Sources 2006, 157 (1), 128-135.

(4) Trimm, D. L. Minimisation of carbon monoxide in a hydrogen stream for fuel cell application. Appl. Catal., A 2005, 296 (1), 1-11.

(5) Ghenciu, A. F. Review of fuel processing catalysts for hydrogen production in PEM fuel cell systems. Curr. Opin. Solid State Mater. Sci. 2002, 6 (5), 389-399.

(6) Newsome, D. S. The water-gas shift reaction. Catal. Rev.-Sci. Eng. 1980, 21 (2), 275-318.

(7) Twigg, M. V.; Spencer, M. S. Deactivation of supported copper metal catalysts for hydrogenation reactions. Appl. Catal., A 2001, 212 (1-2), 161174.

(8) Bunluesin, T.; Gorte, R. J.; Graham, G. W. Studies of the watergas-shift reaction on ceria-supported $\mathrm{Pt}, \mathrm{Pd}$, and $\mathrm{Rh}$ : Implications for oxygenstorage properties. Appl. Catal., B 1998, 15 (1-2), 107-114.

(9) Swartz, S. L.; Seabaugh, M. M.; Holt, C. T.; Dawson, W. J. Fuel processing catalysts based on nanoscale ceria. Fuel Cell Bull. 2001, 4 (30), $7-10$.

(10) Cameron, D.; Holliday, R.; Thompson, D. Gold's future role in fuel cell systems. J. Power Sources 2003, 118 (1-2), 298-303.

(11) Burch, R. Gold catalysts for pure hydrogen production in the watergas shift reaction: Activity, structure and reaction mechanism. Phys. Chem. Chem. Phys. 2006, 8 (47), 5483-5500.

(12) Sakurai, H.; Ueda, A.; Kobayashi, T.; Haruta, M. Low-temperature water-gas shift reaction over gold deposited on $\mathrm{TiO}_{2}$. Chem. Commun. 1997, (3), 271-272.

(13) Andreeva, D.; Idakiev, V.; Tabakova, T.; Ilieva, L.; Falaras, P.; Bourlinos, A.; Travlos, A. Low-temperature water-gas shift reaction over $\mathrm{Au} / \mathrm{CeO}_{2}$ catalysts. Catal. Today 2002, 72 (1-2), 51-57.

(14) Andreeva, D.; Idakiev, V.; Tabakova, T.; Andreev, A. Lowtemperature water-gas shift reaction over $\mathrm{Au} / \alpha-\mathrm{Fe}_{2} \mathrm{O}_{3}$. J. Catal. 1996, 158 (1), 354-355.

(15) Tabakova, T.; Idakiev, V.; Andreeva, D.; Mitov, I. Influence of the microscopic properties of the support on the catalytic activity of $\mathrm{Au} /$ $\mathrm{ZnO}, \mathrm{Au} / \mathrm{ZrO}_{2}, \mathrm{Au} / \mathrm{Fe}_{2} \mathrm{O}_{3}, \mathrm{Au} / \mathrm{Fe}_{2} \mathrm{O}_{3}-\mathrm{ZnO}, \mathrm{Au} / \mathrm{Fe}_{2} \mathrm{O}_{3}-\mathrm{ZrO}_{2}$ catalysts for the WGS reaction. Appl. Catal., A 2000, 202 (1), 91-97.

(16) Idakiev, V.; Tabakova, T.; Naydenov, A.; Yuan, Z. Y.; Su, B. L. Gold catalysts supported on mesoporous zirconia for low-temperature watergas shift reaction. Appl. Catal., B 2006, 63 (3-4), 178-186.

(17) Fu, Q.; Saltsburg, H.; Flytzani-Stephanopoulos, M. Active nonmetallic $\mathrm{Au}$ and $\mathrm{Pt}$ species on ceria-based water-gas shift catalysts. Science 2003, 301 (5635), 935-938.

(18) Yuan, Z. Y.; Idakiev, V.; Vantomme, A.; Tabakova, T.; Ren, T. Z.; $\mathrm{Su}, \mathrm{B}$. L. Mesoporous and nanostructured $\mathrm{CeO}_{2}$ as supports of nano-sized gold catalysts for low-temperature water-gas shift reaction. Catal. Today 2008, 131 (1-4), 203-210.

(19) Luengnaruemitchai, A.; Osuwan, S.; Gulari, E. Comparative studies of low-temperature water-gas shift reaction over $\mathrm{Pt} / \mathrm{CeO}_{2}, \mathrm{Au} / \mathrm{CeO}_{2}$, and $\mathrm{Au} / \mathrm{Fe}_{2} \mathrm{O}_{3}$ catalysts. Catal. Commun. 2003, 4 (5), 215-221.

(20) Fu, Q.; Deng, W. L.; Saltsburg, H.; Flytzani-Stephanopoulos, M. Activity and stability of low-content gold-cerium oxide catalysts for the water-gas shift reaction. Appl. Catal., B 2005, 56 (1-2), 57-68.

(21) Chane-Ching, J. Y. New cerium (IV) cpd.-Easily dispersible in water to form stable sols. EP208580, 1987.

(22) Ginés, M. J. L.; Amadeo, N.; Laborde, M.; Apesteguia, C. R. Activity and structure-sensitivity of the water-gas shift reaction over $\mathrm{Cu}-$ Zn-Al mixed-oxide catalysts. Appl. Catal., A 1995, 131 (2), 283-296.

(23) Leppelt, R.; Schumacher, B.; Plzak, V.; Kinne, M.; Behm, R. J. Kinetics and mechanism of the low-temperature water-gas shift reaction on $\mathrm{Au} / \mathrm{CeO}_{2}$ catalysts in an idealized reaction atmosphere. J. Catal. 2006, 244 (2), 137-152.

(24) Boccuzzi, F.; Chiorino, A.; Manzoli, M.; Lu, P.; Akita, T.; Ichikawa, S.; Haruta, M. Au/ $/ \mathrm{TiO}_{2}$ nanosized samples: A catalytic, TEM, and FTIR study of the effect of calcination temperature on the CO oxidation. J. Catal. 2001, 202 (2), 256-267.

(25) Moe, J. M. Design of water-gas shift reactors. Chem. Eng. Prog. 1962, 58 (3), 33-36.

(26) Ayastuy, J. L.; Gutierrez-Ortiz, M. A.; Gonzalez-Marcos, J. A.; Aranzabal, A.; Gonzalez-Velasco, J. R. Kinetics of the low-temperature WGS reaction over a $\mathrm{CuO} / \mathrm{ZnO} / \mathrm{Al}_{2} \mathrm{O}_{3}$ catalyst. Ind. Eng. Chem. Res. 2005, 44 (1), 41-50.

(27) Amadeo, N. E.; Laborde, M. A. Hydrogen-production from the lowtemperature water-gas shift reaction-Kinetics and simulation of the industrial reactor. Int. J. Hydrogen Energy 1995, 20 (12), 949-956.

(28) Ovesen, C. V.; Stoltze, P.; Norskov, J. K.; Campbell, C. T. A kinetic-model of the water gas shift reaction. J. Catal. 1992, 134 (2), 445468. 
(29) Yurieva, T. M.; Plyasova, L. M.; Kriger, T. A.; Zaikovskii, V. I.; Makarova, O. V.; Minyukova, T. P. State of copper-containing catalyst for methanol synthesis in the reaction medium. React. Kinet. Catal. Lett. 1993, 51 (2), 495-500.

(30) Fujitani, T.; Saito, M.; Kanai, Y.; Kakumoto, T.; Watanabe, T.; Nakamura, J.; Uchijima, T. The role of metal-oxides in promoting a copper catalyst for methanol synthesis. Catal. Lett. 1994, 25 (3-4), 271-276.

(31) Koryabkina, N. A.; Phatak, A. A.; Ruettinger, W. F.; Farrauto, R. J.; Ribeiro, F. H. Determination of kinetic parameters for the water-gas shift reaction on copper catalysts under realistic conditions for fuel cell applications. J. Catal. 2003, 217 (1), 233-239.

(32) Campbell, C. T.; Daube, K. A. A surface science investigation of the water-gas shift reaction on $\mathrm{Cu}(111)$. J. Catal. 1987, 104 (1), 109-119.

(33) Shido, T.; Iwasawa, Y. Reactant-promoted reaction-mechanism for water-gas shift reaction on $\mathrm{ZnO}$, as the genesis of surface catalysis. J. Catal. 1991, 129 (2), 343-355.

(34) Ghiotti, G.; Boccuzzi, F. Chemical and physical-properties of copper-based catalysts for $\mathrm{CO}$ shift reaction and methanol synthesis. Catal. Rev.-Sci. Eng. 1987, 29 (2-3), 151-182.

(35) Shishido, T.; Yamamoto, M.; Atake, I.; Li, D. L.; Tian, Y.; Morioka, H.; Honda, M.; Sano, T.; Takehira, K. Cu/Zn-based catalysts improved by adding magnesium for water-gas shift reaction. J. Mol. Catal. A 2006, 253 (1-2), 270-278.

(36) Grenoble, D. C.; Estadt, M. M.; Ollis, D. F. The chemistry and catalysis of the water gas shift reaction 0.1 . The kinetics over supported metal-catalysts. J. Catal. 1981, 67 (1), 90-102.

(37) Jacobs, G.; Graham, U. M.; Chenu, E.; Patterson, P. M.; Dozier, A.; Davis, B. H. Low-temperature water-gas shift: Impact of Pt promoter loading on the partial reduction of ceria and consequences for catalyst design. J. Catal. 2005, 229 (2), 499-512.

(38) Panagiotopoulou, P.; Christodoulakis, A.; Kondarides, D. I.; Boghosian, S. Particle size effects on the reducibility of titanium dioxide and its relation to the water-gas shift activity of $\mathrm{Pt} / \mathrm{TiO}_{2}$ catalysts. J. Catal. 2006, 240 (2), 114-125.

(39) Frost, J. C. Junction effect interactions in methanol synthesis catalysts. Nature 1988, 334 (6183), 577-580.

(40) Golunski, S.; Rajaram, R.; Hodge, N.; Hutchings, G. J.; Kiely, C. J. Low-temperature redox activity in co-precipitated catalysts: A comparison between gold and platinum-group metals. Catal. Today 2002, 72 (1-2), $107-113$.
(41) Idakiev, V.; Tabakova, T.; Yuan, Z. Y.; Su, B. L. Gold catalysts supported on mesoporous titania for low-temperature water-gas shift reaction. Appl. Catal., A 2004, 270 (1-2), 135-141.

(42) Salmi, T.; Hakkarainen, R. Kinetic-study of the low-temperature water-gas shift reaction over a Cu-ZnO catalyst. Appl. Catal. 1989, 49 (2), 285-306.

(43) Rhodes, C.; Hutchings, G. J.; Ward, A. M. Water-gas shift reaction-Finding the mechanistic boundary. Catal. Today 1995, 23 (1), 43-58.

(44) Karpenko, A.; Leppelt, R.; Cai, J.; Plzak, V.; Chuvilin, A.; Kaiser, U.; Behm, R. J. Deactivation of a $\mathrm{Au} / \mathrm{CeO}_{2}$ catalyst during the lowtemperature water-gas shift reaction and its reactivation: A combined TEM, XRD, XPS, DRIFTS, and activity study. J. Catal. 2007, 250 (1), 139-150.

(45) Rodriguez, J. A.; Liu, P.; Hrbek, J.; Evans, J.; Perez, M. Water gas shift reaction on $\mathrm{Cu}$ and $\mathrm{Au}$ nanoparticles supported on $\mathrm{CeO}_{2}(111)$ and $\mathrm{ZnO}(000(1)$ over-bar): Intrinsic activity and importance of support interactions. Angew. Chem., Int. Ed. 2007, 46 (8), 1329-1332.

(46) Tabakova, T.; Boccuzzi, F. B.; Manzoli, M.; Andreeva, D. FTIR study of low-temperature water-gas shift reaction on gold/ceria catalyst. Appl. Catal., A 2003, 252 (2), 385-397.

(47) Wang, X.; Gorte, R. J.; Wagner, J. P. Deactivation mechanisms for $\mathrm{Pd} /$ ceria during the water-gas-shift reaction. J. Catal. 2002, 212 (2), 225-230.

(48) Deng, W. L.; Flytzani-Stephanopoulos, M. On the issue of the deactivation of Au-ceria and Pt-ceria water-gas shift catalysts in practical fuel-cell applications. Angew. Chem., Int. Ed. 2006, 45 (14), 2285-2289.

(49) Kim, C. H.; Thompson, L. T. Deactivation of $\mathrm{Au} / \mathrm{CeO}_{\mathrm{x}}$ water gas shift catalysts. J. Catal. 2005, 230 (1), 66-74.

(50) Jacobs, G.; Williams, L.; Graham, U.; Thomas, G. A.; Sparks, D. E.; Davis, B. H. Low temperature water-gas shift: In situ DRIFTS-reaction study of ceria surface area on the evolution of formates on $\mathrm{Pt} / \mathrm{CeO}_{2}$ fuel processing catalysts for fuel cell applications. Appl. Catal., A 2003, 252 (1), 107-118.

Received for review July 11, 2008 Revised manuscript received October 1, 2008 Accepted October 16, 2008

IE8010676 